\title{
Vincent Gruis, Sasha Tsenkova \& Nico Nieboer (eds), Management of privatised housing: international policies \& practice
}

\author{
Blackwell Publishing, Chichester, 2009, 288 pp, ISBN 97814051 \\ 81884
}

\section{Christian Lennartz}

Published online: 19 April 2011

(C) The Author(s) 2011. This article is published with open access at Springerlink.com

In the last 20 years, both Eastern and Western European economies have been reshaped by a surge of privatisation in all kinds of industries. In the housing sphere most post-communist Eastern European countries have seen a transition from the command economy in housing provision towards market-driven policies. This shift went together with large-scale sales of public housing units to either sitting tenants or private companies. Strained public budgets, the dominance of a neo-liberal public policy agenda, and the general impetus propelling owner-occupation have spurred the privatisation of public housing in Western countries as well. Although housing privatisation in the latter countries tends to have more facets (e.g. stock transfer to private non-profit housing associations), the sale of public dwellings to sitting tenants has surely been a significant trait of housing system change in Western societies.

The sale of public dwellings to tenants is the starting point of 'Management of Privatised Housing-International Policies and Practice' edited by Gruis, Tsenkova and Nieboer (2009). The editors are well-known experts in the field of social housing management and with this book they have found a true niche, since this may be considered the first major publication linking the sociological debate on privatisation in housing to the organisational view on housing management. With its internationally comparative approach, including four Western (France, The Netherlands, United Kingdom, Switzerland) and five Eastern European countries (Czech Republic, Moldova, Russia, Serbia and Slovenia), as well as China and Australia, the book presents a rich vein of information on how the sales of the public housing stock have been translated into practices, policies and legal frameworks of housing management in different countries. The authors further illustrate how partial sales of the housing stock have led to conflicts between different owners in both day-to-day and long-term management of mixed-ownership housing estates-indeed, a topic which has surprisingly evaded the attention of housing researchers, given the obviousness of the problem.

C. Lennartz $(\bowtie)$

OTB Research Institute of the Built Environment, Delft University of Technology, Delft,

The Netherlands

e-mail: c.lennartz@tudelft.nl 
The structure of the book is straightforward. In the introductory chapter the editors set out the conceptual framework, ensuring that privatisation and housing management in each country are examined in the light of policy/strategy, financial resources, human resources, culture, organisational structure, legal framework, and housing quality. Chapters 2 through 12 focus on the 11 countries. Each country chapter follows an identical outline. A brief overview of the housing context is followed by a thorough description of the privatisation process. Subsequently, management and maintenance issues, as well as potential conflicts, are explored through case studies of partially privatised housing estates. Each author draws conclusions on the main housing management features and challenges referring to the seven aspects. This is illustrated in extensive yet comprehensible tables. Chapter 13 presents the editors' conclusions, mainly relying on a juxtaposition of the tables from the country chapters.

It is very interesting to read about the background and consequences of public housing privatisation in all these countries. Certainly, this book is a repository for scholars and practitioners alike interested in the subject. What makes it remarkable is the editors' decision to include a larger number of both Western European housing systems and postcommunist experiences in Eastern Europe. For one thing, other internationally comparative housing studies tend to include a single Eastern European country as the exotic case, or else they solely focus on Eastern European housing systems. Yet, here we have a book in which a possible East/West divide is at the heart of the research. Interestingly enough, the editors conclude that the biggest gap between countries in management problems is not necessarily of a geographical kind. Rather, it exists between the countries which have adopted a more cautious privatisation approach and those countries where the governments have opted for rapid large-scale sales of public housing estates. It should be noted, though, that post-communist countries tend to follow the latter approach. Finally, the study elucidates the failure of governments, particularly in Eastern Europe, to back up their privatisation policies with a solid legal framework for housing management in mixedownership estates and to provide advice to various owners on how to deal with management problems. Indeed, governments have often acted in a devil-may-care fashion as they neglected their role in the post-privatisation process. Here, the editors clearly emphasise that governments have to assume their responsibilities and should share best-practice experiences in dealing with the most common management issues.

For all its good coverage, this book has still missed some opportunities to provide a more fundamental and foresighted study. Editors of comparative studies always try to strike a balance between a common framework for country analysis and the country expert's freedom to analyse the subject of research from different angles. Here, Gruis et al. have clearly chosen to apply a very, perhaps even overly systematic framework, leading to country chapters that make little effort to go beyond description. This lack of analytical depth comes into full view in the concluding chapter. The editors seem to confuse comparative research with the juxtaposition of the conclusions of the country chapters in a table that stretches across 14 pages. Unsurprisingly, the main finding of the book is then the observable problems in housing management differ along the lines of a country's privatisation process and the specifics of its housing system. It would have been truly instructive if the editors had placed the study in a broader theoretical context by, inter alia, linking country-specific findings as well as their similar experiences on management problems to the wider literature on housing privatisation and management that is cited in the introduction. Furthermore, the study falls short on drawing clearer conclusions about how experiences in (a group of) countries might help to formulate best practices elsewhere. It is not enough to state that there should be well-defined policy guidelines and better resources 
for various owners in all countries. Maybe a profound discussion on the possibilities of exchanging ideas and policies between post-communist countries and the Western world might have been a more fruitful path. Finally, a weakness of the book is the lack of attention given to the country selection. Notwithstanding my enthusiasm for the East/West comparison, I find the actual choice of countries a bit arbitrary.

That said, the editors present a very useful reference book on housing privatisation and management across countries. Keeping in mind their caveat that the book is strictly explorative in nature, it can certainly be considered a good basis for some more fundamental work on the topic in the future.

Open Access This article is distributed under the terms of the Creative Commons Attribution Noncommercial License which permits any noncommercial use, distribution, and reproduction in any medium, provided the original author(s) and source are credited. 